\title{
The Epidemiology of COVID-19, Attitudes and Behaviors of the Community During the Covid Pandemic in Indonesia
}

\author{
Fitriani Kahar ${ }^{1}$, Gufran Darma Dirawan ${ }^{2}$, Sulaiaman Samad $^{3}$, Nurul Qomariyah ${ }^{4}$, Devi Etivia Purlinda ${ }^{5}$. \\ 1,4,5 Lecturer of Politeknik Kesehatan Kemenkes Semarang \\ ${ }^{2}$ Professor of environmental science of Universitas Negeri Makassar \\ ${ }^{3}$ Lecturer of educational science of Universitas Negeri Makassar
}

\begin{abstract}
The rapid development of COVID-19 cases in Indonesia, as well as the spread of COVID-19 which has almost reached all provinces in Indonesia with the number of cases and the number of deaths increasing, has put Indonesia in a public health emergency. The high number of cases of death in Indonesia with CFR $(5.0 \%)$ is very disturbing and worrisome for the community. Our review focuses on the epidemiology of the spread of COVID-19 in Indonesia as well as changes in people's attitudes and behavior during the COVID-19 pandemic. Indonesia is also infected by this virus. COVID-19 in Indonesia first reported two cases on March 2, 2020. On March 11, 2020, for the first time an Indonesian citizen died from Covid-19. East Java Province is the province with the most positive cases found. Because a vaccine that can dispel COVID-19 has not been found, in the end the Stay At Home movement is the most appropriate alternative to reduce the chance of contracting COVID-19 while maintaining cleanliness such as providing disinfectants, using masks, washing hands, exercising physical distance, avoiding crowds and so on. -Other etc. As a result, all activities are hampered, be it in the fields of economy, tourism, and others. Of course, many losses have been caused. However, seen from the obstacles that have occurred, there have been some significant changes that have occurred, especially in the attitude of the community so that they can continue their activities until these attitudes have turned into new habits. What is most visible from changes in community behavior is the discipline of people wearing masks, maintaining physical distance, and always maintaining hand hygiene. In essence, many innovative behaviors suddenly emerged during the COVID-19 outbreak.
\end{abstract}

Keywords:- Epidemiology, COVID-19, Attitude, Behavior, Indonesia.

\section{INTRODUCTION}

Coronavirus $(\mathrm{CoV})$ is a large family of viruses that cause illness ranging from mild to severe symptoms. There are at least two types of coronavirus that are known to cause diseases that can cause severe symptoms such as
Middle East Respiratory Syndrome (MERS-CoV) and Severe Acute Respiratory Syndrome (SARS-CoV). COVID-19 is a new type of virus that has never been previously identified in humans. (1) Covid-19 is a new disease that has spread to several parts of the world with a very fast transmission process, so there is a need for vigilance against this disease. (2) This virus is a positive single-strain RNA virus that infects the respiratory tract, with diagnosis starting from symptoms such as fever, cough or shortness of breath. (3) The latest data globally on July 8,2020 , Covid-19 cases have been reported globally. There were 216 countries in which 11,972,425 confirmed positive cases, 547,111 reported deaths, and 6,918,691 patients who had recovered (4) (5). As of 6 July 2020, the Government of the Republic of Indonesia has reported 64,958 people with confirmed COVID-19. There have been 3,141 reported deaths related to COVID-19 and 29,919 patients have recovered from this disease. (6) The case of the Covid-19 pandemic is not ready for Indonesia to face from the point of view of existing health facilities in Indonesia. (7)

This article aims to determine the characteristics and nature of the corona virus, the epidemiology of the spread of COVID-19 globally and in Indonesia and efforts to prevent and overcome the COVID-19 pandemic. It is hoped that this article can become a source of literature on COVID-19 in Indonesia.

\section{MATERIALS AND METHODS}

This review was carried out with the help of various reference sites such as Google Scholar and WHO data, previous research journals etc. We used key words such as "Indonesia", "Covid-19", "Coronavirus" to get suitable results in relation to Covid-19. Statistical data is collected individually through official Indonesian government websites such as (https://www.covid19.go.id/) and Emerging Infection website (https://covid19.kemkes.go.id/). This research uses content analysis method. This method discusses in depth the contents of written or printed information in the mass media, then a summary of some of these sources is taken so that it becomes a source of reading and reference. 


\section{DISCUSSION}

\section{A. Definition and Characteristics of Coronavirus (SARS-} $\mathrm{CoV}-2$ )

Coronavirus is a type of RNA virus with positive strands with a single chain that is not segmented but encapsulated. (8) Meanwhile, the SARS-Cov-2 virus is a new type of corona virus that has caused an epidemic, with the first case occurring in Wuhan China and reported on December. December 31, 2019. (9)

This Corona virus is included in the order Nidovirales, the Coronaviridae family and the Orthocoronavirinae subfamily, which are divided into $\alpha, \beta, \gamma$, and $\delta$ groups according to their serotypic and genomic characteristics. (10) (8)

The structure of the Coronavirus is a cube-like $\mathrm{S}$ protein located on the surface of the virus. There are 4 main protein structures in Coronavirus: Protein N (nucleocapsid), Glycoprotein M (membrane), Glycoprotein Spike S (spike), protein E (sheath). Protein E Protein S functions as a receptor so that the virus can enter the host cell. It is named the Corona virus because it corresponds to its crown-like characteristics on its surface. (10) (8) (11) The structure of the Coronavirus can be seen in Figure 1.

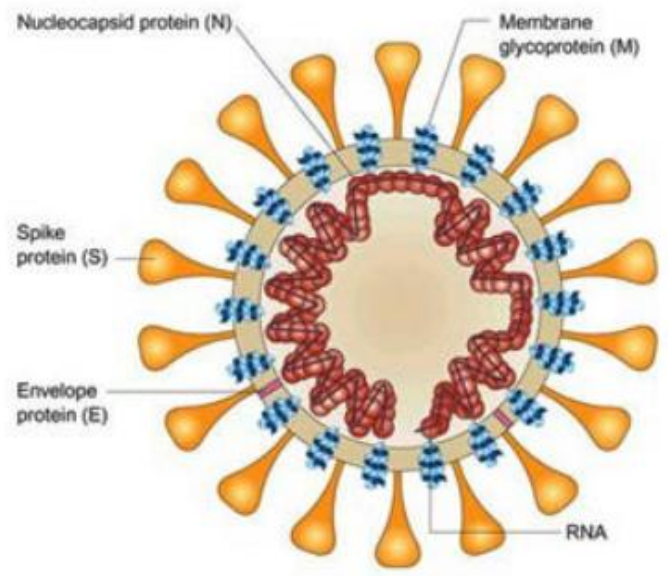

Fig 1:- Structure of Corona Virus (12)

\section{B. Epidemiology}

The World Health Organization named the new virus Severe acute respiratory syndrome coronavirus-2 (SARSCoV-2) and the name of the disease as Coronavirus disease 2019 (COVID-19). (9) In December 2019 to be precise on the 29th, it was reported from the city Wuhan Hubei Province, China that there are four initial cases of acute respiratory syndrome with unknown etiology that are thought to be related to the local seafood market ("wet market"). (13) (9) The role of the Huanan seafood wholesale market remains unclear, but the large number of COVID-19 cases linked to this market indicate that SARSCov-2 was transmitted from animals to humans. (14)
Looking at the data collected from the WHOCoronavirus Disease (COVID-2019) situation report, the Center for System Science and Technology (CSSE) from Johns Hopkins University and the Worldometer database, on July 8, 2020, as many as 216 countries had reported COVID-19 cases. 11,972,425 people are infected with coronavirus, with a death toll of 547,111 people worldwide with a CFR of $4.7 \%$, and as many as $6,918,691$ people who have recovered. At the beginning of the disease outbreak, the continent of Asia was the continent most affected by this virus, especially China, which was the first country to report a case of COVID-19. However, currently the most COVID-19 cases are found in the European continent, especially the United States and Brazil. This shows a dramatic change in the epidemiological dynamics of COVID-19. (5) (4) (15)

Thailand is the first country outside China to report cases of COVID-19. After Thailand, the next countries that reported the first causes of COVID-19 were Japan and South Korea which then developed to other countries. (16) For the spread of cases in ASEAN countries on July 8, 2020 it was reported that Indonesia was the country with the highest confirmed cases. namely there are 66,226 positive cases of COVID-19 with a CFR of $5.0 \%$, this figure is also the highest in Southeast Asia. The next highest positive case reports in ASEAN were Singapore with 44,983 cases, the Philippines with 46.33 cases, Malaysia with 8,668 cases, Thailand 3,195 cases, Vietnam 369 cases, Myanmar 316 cases, Brunei Darussalam 141 cases, Cambodia 141 cases , and lastly was Laos with 19 cases. (17) Due to the potential for the SARS-CoV-2 pandemic, careful surveillance is essential to monitor future host adaptation, virus evolution, infectivity, transmission, and pathogenicity (18).

For the case of COVID-19 in Indonesia itself, where on March 11, 2020, for the first time an Indonesian citizen died from Covid-19. On July 8, 2020, Indonesia was reported as the country with the highest positive cases among ASEAN countries, namely 66,226 positive cases. (17) Data from the INA Cluster also reported the development of COVID-19 cases, namely 66,226 positive cases, 30,785 recovered cases and 3,309 cases that died with a Case Fatality Rate (CFR) of 5.0\% . (17) (19)

Figure 2 is the development of COVID-19 cases in Indonesia from March-August 2020.

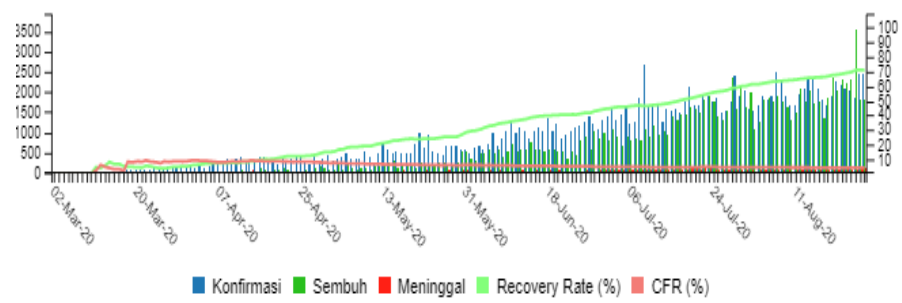

Fig 2:- Graph of COVID-19 Cases in Indonesia (20) 
In Figure 2 is a graph of COVID-19 cases in Indonesia from early March to August 2020, where a positive confirmation case chart continues to increase every month. (20) This should be a global concern to reduce the spread of Covid-19 cases. .

Figure 3 is the provincial data with the most positive cases of COVID־רריר-19 on July 8, 2020.

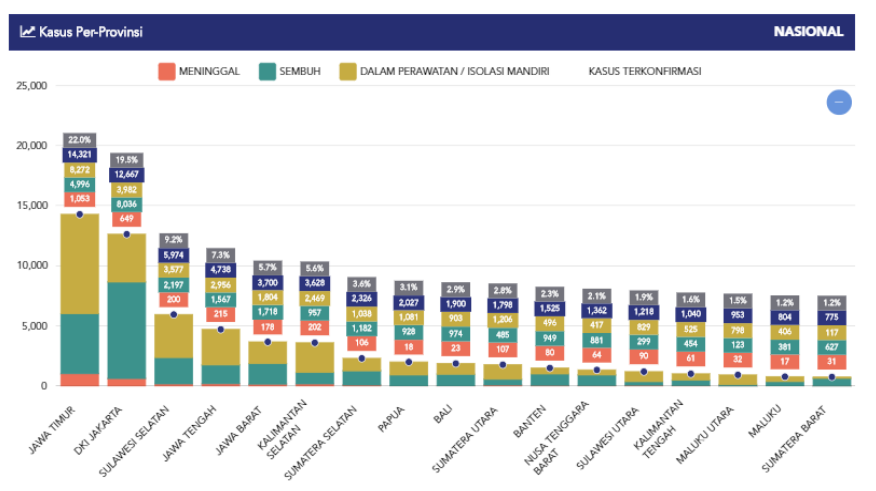

Fig 3:- Graph of the Distribution of COVID-19 in Indonesia

In Figure 3 is a graph of the most positive confirmations throughout Indonesia with the highest to lowest distribution being East Java, DKI Jakarta, South Sulawesi, Central Java, West Java, South Kalimantan, South Sumatra, Papua, Bali, North Sumatra, Banten, West Nusa Tenggara. , North Sulawesi, Central Kalimantan, Maluku, and West Sumatra. (21) East Java Province is the province in Indonesia with the most positive cases.

\section{Transmission}

At first, the transmission / transmission of the corona virus was not known whether it could transmit from human to human. Furthermore, it was reported that there was a case of 15 medical workers who were infected by one of the patients who were suspected of being infected with pneumonia caused by a new strain of coronavirus. (22) So it is reported that the transmission of this coronavirus can be transmitted from human to human. (23) This Coronavirus spreads by means of mysteriously until recently. (3)

Transmission of COVID-19 is by droplets emitted when speaking or sneezing within 2 meters, or by coming into contact with an open surface. Fifty percent of transmission occurs secondary to exposure to asymptomatic people. In fact one sign of COVID-19 infection is symptomatic anosmia (see below) in asymptomatic patients without nasal obstruction. In addition, patients can transmit the infection for up to 2 weeks after recovering from symptoms of the disease. Fecal-oral fecal transmission has been reported unlikely. Perinatal transmission has not been detected. (15)

Airborne transmission can occur in conditions that produce aerosols, such as: endotracheal intubation, bronchoscopy, open suctioning, nebulizer therapy, taking nasopharyngeal swabs, moving the patient to the prone position, releasing the patient from the ventilator, tracheostomy, cardiopulmonary resuscitation, and centrifugation in the laboratory. 24) (25)

\section{Pathogenesis of Corona}

SARS-CoV-2 has strong pathogenicity and transmission, it is more contagious than SARS-CoV and MERS-CoV. This virus can last up to three days with plastic and stainless steel SARS CoV-2 can last up to three days or in aerosols for three hours. The virus has also been found in feces, but as of March 2020 it was not known whether fecal transmission was possible, and the risk is expected to be low. (26)

Knowledge of the physical and chemical characteristics of the corona virus is obtained based on previous studies on SARSr-CoV and MERSr-CoV. The corona virus is sensitive to ultraviolet and heat rays, and can be effectively inactivated by heating at $56^{\circ} \mathrm{C}$ for 30 minutes and lipid solvents such as ether, $75 \%$ ethanol, disinfectants containing chlorine, peroxyacetic acid, and chloroform (except chlorhexidine) (27)

The development of SARS-CoV-2 depends on the interactions between the virus and the individual's immune system. Viral factors include virus type, mutation, viral load, viral titer, and virus viability in vitro. Individual immune system factors include genetics (such as the HLA gene), age, gender, nutritional status, immuneneuroendocrine regulation, and physical status. All of these factors contribute to whether the individual is infected with the virus, the duration and severity of disease, and reinfection (28).

\section{E. Clinical Symptoms}

People with COVID-19 have a variety of reported symptoms ranging from mild symptoms to severe illness. Symptoms can appear 2-14 days after exposure to the virus. The incubation period is 0-14 days. People with these symptoms may be infected with COVID-19: fever / chills, cough, shortness of breath, muscle aches, headache, loss of feeling, sore throat, nasal congestion, nausea / vomiting, and diarrhea (29).

\section{F. Risk Factors}

The people who have risk factors for COVID-19 are: age, smoking history, exposure history (contact history, residence history, travel history), comorbidities (hypertension, diabetes mellitus, CHD, COPD, Chronic Kidney, etc.) , SOFA (Sequential Organ Failure Assessment) score. (30)

\section{G. Prevention}

The prevention and control of Covid-19 is divided into two levels, namely prevention at the individual level and prevention at the community level. For individual level prevention efforts include personal and home hygiene efforts, controlling comorbids. Meanwhile, community level prevention includes limiting physical interactions (physical contact / physical distancing), implementing 
cough etiquette, wearing masks, health quarantine, and social distancing (31).

The COVID-19 pandemic is a global problem that has occurred in more than 200 countries around the world. Indonesia is also one of the countries most affected by this virus. The Indonesian government anticipated this pandemic case too late, resulting in so many cases. (32) Several steps and policies have been taken by the Indonesian government, but this strategy will not be successful if it is not supported by cross-related sectors or all elements of society. Therefore, participation from across sectors and communities is highly expected for the success of programs and policies that have been taken by the government to prevent the increasingly widespread spread of COVID-19 in Indonesia.

During the COVID-19 pandemic, the community needed to carry out a new adaptation concept called NEW Normal. Demands needs that require people to stay active (working, trading, socializing, and self-actualizing). Adaptation to new habits is defined as a condition in which people can carry out their daily activities by adapting to live side by side with COVID-19. With new regulations, new lifestyles and new habits, it is hoped that the community will remain healthy, fit and productive. In the concept of new adaptations in this activity, the community is required to implement the principles of health protocols through GERMAS COVID-19, namely maintaining distance, washing hands with soap or Hand Sanitizer (CTPS), using masks, maintaining immunity and controlling comorbidities. (30)

\section{The impact of COVID-19 on people's attitudes and behavior}

\section{$>$ Change of attitude}

Due to the dominance of patients with mild symptoms and the easy spread of COVID-19 when there is interaction and vaccines that do not yet exist (the official QA WHO website), which creates a great chance of being infected, the most pronounced impact on people's attitudes is Physical Distancing or Social Distancing where each each individual must have distance to interact and are advised to Stay At Home. As a result, the individualist side of society eventually emerged over time this quarantine. This can be seen when some people who, for example, have an urgency and are forced to leave their homes, which were previously 'labeled' as a friendly society, eventually become someone who tends to communicate only as needed, who previously were pressed for no problem, now approaching other individuals is already anxious. . These things are still part of the change in attitude that has occurred.

Based on the previous discussion, it can be concluded that some of the changes in attitude during the COVID-19 pandemic (at several points were specifically from an economic perspective) as follows:

- The frequency of interaction is getting smaller. Interaction between individuals is necessary because they are mostly at home.
- When making transactions to meet their needs, people tend to use platforms in markets and make transactions by relying on e-wallets, m-banking, sms banking, or internet banking so that there is no physical contact with couriers, cashiers, and other intermediaries.

- All activities are transferred online. For some people this triggers a "relaxed" attitude because they are free in the process even though there are still official rules from each agency in carrying out activities online.

- People are more aware of the importance of clean living, by providing disinfectant products, washing hands, and being diligent in cleaning themselves and using masks when going out of the house.

- Comply with regulations and policies related to COVID-19.

- Each individual tends to be selfish.

- Although it did not last long, Panic Buying occurred during the early days of COVID-19 spreading in Indonesia. Of course, this is

- is one of the negative attitudes generated by the COVID-19 pandemic.

- Changes in attitude due to decreased mental health. This is usually caused by the fact that people are too panicked when responding to the latest information so that they are stressed and lead to changes in attitudes, for example, more irritability, fear, overdoing anything related to COVID-19, and others.

- Non-millennial internet users are increasing. They previously did not care, lacked knowledge about the internet, less desire to use the internet because it was considered complicated, now they tend to use the internet to support their activities.

- Previously, people tended to buy things online because of their desire, but because of the COVID-19 pandemic, online purchases have shifted to purchasing necessities.

- From indulgence to utility applies to the attitude of society as consumers who avoid eating out and turn to delivery service. Actually, this has happened a lot even before the pandemic, but the context is that people use these delivery services for indulgence types of food that aim for pleasure and enjoyment such as boba, pizza, chicken geprek, burgers, etc. will shift to food that is utility for needs. daily. From ordering once to booking again.

- COVID-19 revives home cooking, most of the people rarely cook at home, but with Due to this pandemic, they tend to hone their cooking skills by following various recipes on the internet. Not even infrequently spice up these skills with a myriad of creativity in them.

- For those who have pets, the interaction between the two becomes more.

There have been many changes in attitudes that have occurred in society during the COVID-19 pandemic. Until now, the COVID-19 pandemic has yet to show signs of ending, while many hampered activities (especially the economy) are able to support people's lives. (33) (34) 


\section{$>$ Changes in behavior}

During the COVID-19 pandemic there was a change in people's behavior. The main change that is most visible is the number of people who have followed the government's recommendation to implement health protocols such as wearing masks, diligently washing hands, maintaining distance and other health protocols. Regarding the use of masks, the community has not yet reached the level of understanding. The public does not understand the importance of using masks, people are forced to use masks and follow government regulations. This shows the importance of education to implement health protocols in all areas of life (35)

Concerns related to the Covid-19 pandemic have a positive impact on society because people will become more concerned about cleanliness and health. Judging from the survey, 85 percent of people are more concerned with hand hygiene, 55 percent consume water more often. The survey results also show that personal hygiene is important and focus on hand hygiene is the main (36)

Another behavior change is the habit (or folkways) of the Indonesian people from various circles to gather, socialize, and chat in a social order that tends to be a crowd (such as markets, celebrations, and invitations). This habit must be changed in the sense of doing so but online (online meetings, online shopping, and online events). Doing social distancing. The behavior that must be changed is the distance between people of about 1 meter or more. This is to help reduce the chance of infection between people. However, it will take time for people to adjust to these changes, which can be accelerated if there are incentives from the government (34)

Changes in the behavior of the general public will also certainly help save the lives of those who are threatened with infection and of course, in accordance with initiatives from various countries in the world, flatten the curve (reducing the number of infections so that the total number of sick people is within the capacity of the country's health system) thus reducing the burden. in hospitals (due to limited beds and ventilators in each hospital) and save lives (34).

In Indonesia, it is currently doing social distancing, but what the Government of Indonesia lacks is a lack of good public communication, and Indonesia must encourage community participation. An unprecedented time requires extraordinary action. Behavioral research has had to adapt to relying more on experiments or online surveys. Currently, there are ample opportunities for research, but it requires time and theoretical guidance to be properly tested using economic experiments (37)

In general, it can be concluded that change can be divided into several categories, namely changes in behavior including healthy living behavior, behavior using technology, behavior in education, behavior using social media, consumptive behavior, work behavior, and socioreligious behavior (37). Regarding healthy living habits, healthy living habits will change for the better, by consuming a balanced healthy diet, exercising and sleeping regularly, checking health conditions more regularly, looking for reliable health insurance, maintaining cleanliness, and using tools or consuming supplements. to avoid disease. Healthy behavior is not limited to physical health but also mental health. In addition to healthy living habits, people's behavior has also changed in the era of COVID-19 in the use of technology, especially digital technology. Digital technology for online communication, robotic technology, and non-contact based technology equipment are as important as electricity, water and even oxygen.

In the education sector, for example, teachers and students will use more search engines and Massive Open Online Courses (MOOC) such as Udemy, Coursera, Teacher Room. Teachers and students will also get used to conducting distance learning interactions using facilities such as Google Meet, Microsoft Teams, Cisco Webex, Zoom, google classroom, WAG, and email. In the behavior of media use, the public tends to disseminate information without considering its accuracy. Regarding consumer behavior, the COVID-19 outbreak will make people adopt anti-consumer behavior. They will choose a simpler life (Life Simplifiers), by only buying the items needed in the amount that suits their needs. In terms of work behavior, during their work the community must remain obedient and carry out behavior according to Health protocols. Entrepreneurial behavior (entrepreneurship) develops more in society.

Helpful behavior or social behavior, such as providing soft loans and donations as well as other donations have developed quite a bit in society during the COVID-19 outbreak. Not only in the upper middle class, but ordinary people also realize the importance of helping others, for example providing free food or other basic necessities. In terms of religion, society will give more value about the importance of family life, friends and community. The COVID-19 outbreak also raises awareness of the vulnerability of human life as a whole so that religious behavior and spirituality will be of higher quality. People are becoming more aware of the meaning of religious rituals and their relation to spiritual maturity by viewing them as a process of seeking something more important. (38)

\section{CONCLUSION}

The rapid development of COVID-19 cases in Indonesia, as well as the spread of COVID-19 which has almost reached all provinces in Indonesia with the number of cases and the number of deaths increasing, has put Indonesia in a state of public health emergency. The high number of cases of death in Indonesia with CFR (5.0\%) is very disturbing and worrisome for the community. This pandemic causes changes in people's attitudes and behavior on a daily basis, but this has a positive impact on people's attitudes and behavior because with this pandemic people are more aware and concerned about the importance of 
clean and healthy living. What is most visible from changes in community behavior is the discipline of people wearing masks, maintaining physical distance, and always maintaining hand hygiene. In essence, many innovative behaviors suddenly emerged during the COVID-19 outbreak.

\section{REFERENCES}

[1]. Ministry of Health RI. Guidelines for Coronavirus Disease (COVID-19) Prevention and Control Revision 3. Jakarta: Indonesian Ministry of Health, Director General of P2P; 2020. 0-115 p.

[2]. Susilo A, Rumende CM, Pitoyo CW, Santoso WD, Yulianti M, Sinto R, et al. Coronavirus Disease 2019: Updated Literature Review Coronavirus Disease 2019: Review of Current Literatures. J Indonesian Internal Medicine. 2020; 7 (1): 45-67.

[3]. Yuliana. Corona virus diseases (Covid -19); A literature review. Wellness Heal Mag [Internet]. 2020; 2 (1): 187-92. Availablefrom:https://wellness.journalpress.id/wellnes s/article/view/v1i218wh

[4]. Worldometer. Coronavirus Update (Live): Cases and Deaths from COVID-19 Virus Pandemic [Internet]. Worldometers. 2020 [cited 2020 Apr 8]. p. 1. Available

from:https://www.worldometers.info/coronavirus/\%0 Ahttps://www.worldometers.info/coronavirus/?

[5]. Johns Hopkins Coronavirus Resource Center. COVID-19 Map - Johns Hopkins Coronavirus Resource Center [Internet]. Johns Hopkins Coronavirus Resource Center. 2020 [cited 2020 Apr 8]. Available from: https://coronavirus.jhu.edu/map.html

[6]. WHO. Novel Coronavirus July 6, 2020 [Internet]. World Health Organization. 2020 [cited 2020 Jul 9]. Available

from:https://www.who.int/indonesia/news/novelcoronavirus

[7]. Setiati S, Azwar MK. COVID-19 and Indonesia. Acta Med Indones. 2020; 52 (1): 84-9.

[8]. Wang Z, Qiang W, Ke H. A Handbook of 2019-nCoV Pneumonia Control and Prevention. Hubei Sci Technol Press. 2020; 1-108.

[9]. WHO. Novel Coronavirus (2019-nCoV) situation report, 1.2020.

[10]. Li G, Fan Y, Lai Y, Han T, Li Z, Zhou P, et al. Coronavirus infections and immune responses. J Med Virol. 2020; 92 (4): 424-32.

[11]. PDPI. Pneumonia COVID-19 Diagnosis \& Management in Indo INDONESIA. Jakarta: PDPI; 2020.

[12]. Dogra A, Goyal B, Sharma AM. Corona Virus: A Novel Outbreak. Biomed Pharmacol J. 2020; 13 (March): 5-10.

[13]. Adhikari SP, Meng S, Wu Y, Mao Y, Ye R, Wang Q, et al. Novel Coronavirus during the early outbreak period: Epidemiology, causes, clinical manifestation and diagnosis, prevention and control. Infect Dis Poverty [Internet]. 2020; 9 (29):1-12.Available from: https://link.springer.com/article/10.1186/s40249-02000646-X

[14]. Li Q, Guan X, Wu P, Wang X, Zhou L, Tong Y, et al. Early transmission dynamics in Wuhan, China, of the novel coronavirus-infected pneumonia. N Engl J Med. 2020; 382 (13): 1199-207.

[15]. Ortiz-Prado E, Simbaña-Rivera K, Gómez-Barreno L, Rubio-Neira M, Guaman LP, Kyriakidis NC, et al. Clinical, molecular and epidemiological characterization of the SARS-CoV2 virus and the Coronavirus disease 2019 (COVID-19), a comprehensive literature review. Diagnosis of Microbiol Infect Dis [Internet]. 2020; 98 (1): 115094. Available from: https://doi.org/10.1016/j.diagmicrobio.2020.115094

[16]. Ministry of Health RI. Guidelines for the Prevention and Control of Coronavirus Disease (COVID-19) Revision 5. 5th ed. Aziza L, Aqmarina A, Ihsan M, editors. Jakarta: Ministry of Health RI; 2020. 1-214 p.

[17]. Ministry of Health of the Republic of Indonesia. Recent Development Situation (COVID-19). May 05 [Internet]. 2020; 17-9. Available from: https://covid19.kemkes.go.id/download/Situasi_Terki ni_050520.pdf

[18]. Harapan H, Itoh N, Yufika A, Winardi W, Keam S, Te $\mathrm{H}$, et al. Journal of Infection and Public Health Coronavirus disease 2019 (COVID-19): A literature review. J Infect Public Health [Internet]. 2020; 13 (5): 667-73. Available from: https://doi.org/10.1016/j.jiph.2020.03.019

[19]. Task Force for the Acceleration of Handling COVID19 RI. Home | Task Force for the Acceleration of Handling COVID-19 [Internet]. Home covid19.go.id. 2020 [cited 2020 Jul 9]. p. 1-1. Available from: https://covid19.go.id/

[20]. Ministry of Health-RI. Home »Information on Emerging Infection Ministry of Health RI [Internet]. Ministry of Health. 2020. Available from: https://infemerging.kemkes.go.id/

[21]. Task Force for the Acceleration of Handling COVID19 RI. Distribution Map | Task Force for the Acceleration of Handling COVID-19 [Internet]. Covid19.Go.Id. 2020 [cited 2020 Jul 8]. Available from: https://covid19.go.id/peta-sebaran

[22]. (CNA) CNA. Wuhan virus outbreak_ 15 medical workers infected, 1 in critical condition. 2020.

[23]. Relman E. Deadly China Wuhan virus spreading human to human, officials confirm - Business Insider. 2020.

[24]. WHO. Modes of transmission of virus causing COVID-19 implications for IPC precaution recommendations. 2020.

[25]. Aryati. Laboratory aspects of COVID-19: serology and PCR. Topics for discussion. Jakarta: PDSPatKlin; 2020.

[26]. Ministry of Home Affairs. General Guidelines for Dealing with the Covid-19 Pandemic for Pencehagan Regional Government, Control, Diagnosis, and Management. Jakarta; 2020. 
[27]. PRC KKN. Guide to Coping with Coronavirus Disease 2019: Prevention, Control, Diagnosis and Management. Translated Edition. L E, Teli M, Fanggidae V, editors. Kupang;

[28]. Li X, Geng M, Peng Y, Meng L, Lu S. Molecular immune pathogenesis and diagnosis of COVID-19. Vol. 10, Journal of Pharmaceutical Analysis. 2020.

[29]. CDC. Symptoms of Coronavirus _ CDC [Internet]. 2020 [cited 2020 Jul 12]. Available from: https://www.cdc.gov/coronavirus/2019-

ncov/symptoms-testing/symptoms.html May 13, 2020

[30]. Director General of disease prevention and control. Government Policy in Combating COVID-19 in Indonesia through the One Health Webinar Approach. Semarang UNDIP; 2020.

[31]. Monardo D, Adisasmito W. Guidelines for Rapid Medical and Public Health Handling of Covid-19 in Indonesia Task force for accelerating the handling of covid-19 In Jakarta: Covid-19 Task Force; 2020. p. $1-39$.

[32]. Katadata. Indonesia Anticipated Late Covid-19 Pandemic - Katadata Data Analysis. 2020

[33]. Yuswohady. Predicting changes in Consumer Behavior in the New Normal. Infobrand. https://infobrand.id/ predicting changes in consumerbehavior-in-new-normal.phtml. 2020.

[34]. Jeffaya Amadeo Basen. 2020. Changes in the Behavior of Upper and Lower Class Communities in Facing COVID-19: Class Solidarity and Its Potential for Indonesia. https://fisip.ub.ac.id/?p=10285\&lang=id May 12, 2020.

[35]. Firmansya Rian. Unpad Anthropologist Reveals Changes in Community Behavior During the Covid19 Pandemic. https://prfmnews.pikiranrakyat.com/gaya-hidup/pr-13400625/ahli-antropologiunpad- disclosed-perubah-perjual-masyarakat-selamapandemi-covid-19. 12 June 2020

[36]. Ansori ade Nasihuddin. Changes in Community Behavior That Happened During the COVID-19 Pandemic in Indonesia. https://www.liputan6.com/health/read/4258205/perub ah-perakuan-masyarakat-yang-terjadi-selamapandemi-covid-19-di-indonesia. 20 May 2020

[37]. Budiarso Sony. Zuhri Leila Chanif. The Covid-19 Pandemic Changes Policy, Behavior and Research. https://feb.ugm.ac.id/id/berita/2976-pandemi-covid19-mengubah-keb Policy-perakuan-dan-pen Research. 21 May 2020

[38]. Ginting Henndy. 2020. Behavior Changes in Response to the Covid-19 Outbreak. https://himpsi.or.id/blog/materi-edukasi-covid-195/post/perubah-peradilah-sebagai-respon-terhadapwabah-covid-19-127 4 June 2020. 